\title{
EMENDAS AO ORÇAMENTO E O DESEQUILÍBRIO DE PODERES
}

Coluna publicada em 3.7.2012: <http://www.conjur.com.br/2012-jul-03/ contas-vista-emendas-orcamento-desequilibrio-poderes $>$

A chamada "CPI do Cachoeira" trouxe de volta ao debate questão que há muito reclama solução em nosso processo orçamentário. Noticiou a imprensa recentemente um "pico" de "liberação" de emendas parlamentares por ocasião da formação da referida CPI, fato constatado também em outras oportunidades. ${ }^{1}$

Toda a problemática deste tema requer uma explicação ao leitor sobre o funcionamento do nosso sistema de elaboração da lei orçamentária anual (LOA) dos entes federados, que é interessante explicitar, a fim de que se possa ter uma exata compreensão do problema e a dimensão de sua importância no funcionamento de nossa democracia representativa e, com isso, chamar a atenção para este já velho problema, esperando que possa provocar a reflexão para possíveis soluções.

Os entes que compõem a Federação brasileira - União, estados, Distrito Federal e municípios - têm sua atividade financeira explicitada nas leis orçamentárias, de vigência anual, compreendendo as receitas e despesas para o exercício financeiro. Nela estão definidos os destinos dos recursos públicos e, portanto, onde e como será aplicado o seu, o meu, o nosso dinheiro. Definem-se quais programas e respectivas ações governamentais serão implantados, continuados, encerrados, quanto se destinará a cada um, evidenciando as políticas públicas que cada esfera de governo desenvolverá durante o período. Faz da lei orçamentária, como já reconheceu o ministro Carlos Ayres Britto, a lei infraconstitucional mais importante para o país. ${ }^{2}$

1 Gasto do governo com varejo político dispara após a crise. Liberações para emendas parlamentares agora superam R\$ 350 mi por mês. Folha de S.Paulo, cad. Poder, 6 de maio de 2012.

2 "Abaixo da Constituição, não há lei mais importante para o país, porque a que mais influencia o destino da coletividade" (STF, Tribunal Pleno, ADI 4.048-MC/DF, rel. Min. Gilmar Mendes, j. 14.5.2006, voto do Min. Carlos Britto, p. 92). 
Delicada, portanto, a questão da distribuição das atribuições entre os Poderes quando se trata da lei orçamentária. Nosso ordenamento jurídico prevê que a iniciativa legislativa é privativa do Poder Executivo, submetendo-se o projeto encaminhado ao Poder Legislativo para deliberação e aprovação. Aprovada a lei, o Poder Executivo assume o comando da execução orçamentária, e todo o processo é fiscalizado pelos sistemas de controle interno e externo das finanças públicas, este último sob o comando do Poder Legislativo, com auxílio dos Tribunais de Contas. Vê-se haver uma razoavelmente bem distribuída partilha de atribuições no que tange às leis orçamentárias, que, se não fossem as distorçôes causadas pelo mau uso do sistema, comporia um bem construído processo orçamentário. Mau uso este que, como se verá, ocorre justamente na questão das emendas parlamentares.

E onde estão essas distorções?

Em sendo uma lei, o orçamento público submete-se ao crivo do Poder Legislativo, a quem cabe deliberar sobre a proposta encaminhada pelo Poder Executivo, podendo, por conseguinte, alterá-la. Isto se dá por meio as emendas parlamentares, cuja regulamentação está constitucionalmente prevista no artigo $166, \mathbb{3} 3^{\circ}$, da Constituição Federal.

Apresentado o projeto de lei orçamentária ao Poder Legislativo, no segundo semestre de cada ano, ${ }^{3}$ os parlamentares oferecem suas emendas, que, em tese, sujeitam-se tão somente às limitações estabelecidas no artigo $166, \$ 3^{\circ}$, exigindo-se compatibilidade com o plano plurianual e lei de diretrizes orçamentárias, sendo vedadas emendas que incidam sobre dotações para pessoal, serviços da dívida e as transferências intergovernamentais. E o mais relevante: indiquem os recursos necessários para atendê-las, admitidos apenas os provenientes de anulação de despesas. Ou seja: não cabe aos parlamentares "criar receita" para atender suas emendas parlamentares.

Apresentar emendas, propondo novas opções de gastos, com a indicação dos recursos necessários para atendê-las, importando em cortar outras despesas já incluídas no projeto de lei orçamentária pelo Poder Executivo, evidentemente causará uma grande disputa política pela respectiva aprovação, com a dificuldade prática de analisar as milhares de emendas apresentadas pelas centenas de senadores e deputados, ${ }^{4}$ cada uma com sua peculiaridade de inclusão de uma nova despesa com

3 Mais precisamente, na esfera federal, no final do mês de agosto, em cumprimento ao disposto no artigo $35, \$ 2^{\circ}$ do ADCT, que determina seja o projeto apresentado quatro meses antes de findo o exercício financeiro.

481 Senadores e mais de 500 deputados na esfera federal compõem o Congresso Nacional, responsável pelo Orçamento da União. 
o recurso oriundo do corte de outra despesa, tudo isso no exíguo prazo de menos de quatro meses.

A praxe dos Parlamentos praticamente consolidou a sistemática de definir previamente, em acordo entre os líderes de ambos os Poderes, uma "cota" para as emendas parlamentares, estabelecendo-se um montante fixo, a ser contabilizado em rubrica específica durante a tramitação do projeto, para servir de "fonte de recursos" para atender a demanda das emendas parlamentares.

Duas graves distorções na participação do Poder Legislativo - e, por conseguinte, da vontade popular - no processo orçamentário se vislumbram a partir dessa prática: a primeira delas é a redução da influência dos parlamentares no orçamento público, que, exceto no que se refere ao montante destinado à "cota das emendas parlamentares", pouco ou nada interferem na elaboração da peça orçamentária, e, portanto, na decisão sobre a alocação dos recursos públicos; a segunda é a limitação da ação dos parlamentares à inclusão de despesas de caráter eminentemente paroquial e localizado, visando atender a demandas de menor vulto, geralmente destinadas a interesses específicos de sua base de apoio eleitoral. Inviabiliza, por conseguinte, a participação efetiva dos representantes do povo, eleitos para compor o Parlamento, na definição das políticas públicas e nas grandes questóes relacionadas à alocação dos recursos, fazendo do Poder Executivo praticamente o único responsável pelas escolhas que vão definir os programas a serem cumpridos pelo ente federado.

Mas o pior ainda está por vir e é o que fica claramente evidenciado na notícia referida no início deste texto.

Aprovada e publicada a lei orçamentária, inicia-se a fase de execução, na qual as despesas se concretizarão, com a efetiva entrega dos recursos que constam das dotações orçamentárias para o cumprimento dos programas governamentais nela estabelecidos.

Nesse processo, compete ao Poder Executivo comandar a liberação dos recursos, e as várias circunstâncias que envolvem as inevitáveis e sempre presentes imperfeições na previsão de arrecadação e mesmo no fluxo das despesas tornam necessário haver mecanismos de flexibilidade que permitam a adequação das liberações de recursos ao ingresso de receitas.

Entre os vários instrumentos está o contingenciamento (ou limitação de empenho, nos termos da legislação vigente), por meio do qual não se autorizam as despesas até que se torne adequada e oportuna a respectiva liberação, descontingenciando-se, então, os valores orçados e efetivando-se a entrega do dinheiro. Criado para adaptar o fluxo de entrada com a saída de recursos, permitindo um 
adequado gerenciamento das finanças, o que se vê é uma distorção no uso desse instrumento.

Uma vez que se sabem quais as dotações orçamentárias inseridas no orçamento pelas emendas parlamentares, cuja liberação dos recursos é de evidente interesse do parlamentar que a patrocinou, o contingenciamento das referidas dotações, para liberação oportuna, transformou o processo orçamentário em verdadeiro instrumento de "compra" de apoio político do Legislativo por parte do Executivo. As dotaçôes consignadas às emendas parlamentares são liberadas, como se tem reiteradamente constatado, por razões de interesse político, e não financeiro. Desvia-se, dessa forma, o contingenciamento, instrumento de flexibilidade orçamentária destinado a melhor gerenciar o fluxo de recursos, de sua verdadeira finalidade, que é adaptar as inconstâncias da atividade financeira para buscar atingir o fiel cumprimento da lei orçamentária tal como aprovada, para outra que não lhe é própria, a saber, a de moeda de troca entre os Poderes por apoios políticos circunstanciais.

A análise da liberação de recursos contingenciados contemplados por emendas parlamentares, mostrando coincidência com as datas de votaçôes importantes no Congresso Nacional, tal como constatado pela imprensa, não deixa margem a dúvidas sobre esse desvio de finalidade que se vem constatando no processo orçamentário. ${ }^{5}$

Urge aproveitar mais essa oportunidade em que o tema volta à tona para que se intensifiquem os esforços no sentido de criar mecanismos mais eficientes de participação do Poder Legislativo no processo orçamentário, bem como de controle da atividade de execução orçamentária pelo Poder Executivo, a fim de que o Orçamento Público cumpra seu papel de lei, que, de fato, represente as escolhas da população sobre a aplicação dos recursos públicos e sejam estas cumpridas tal como aprovadas.

5 R \$ 84,5 milhões em 9 de março de 2012, logo após a rejeição, pelo Senado, de indicação para a ANTT; R \$ 47,5 milhões em 27 de março de 2012, véspera da votação da Lei Geral da Copa; e R \$ 40,3 milhóes em 20 de abril de 2012, dia seguinte à criação da "CPI do Cachoeira" (notícia citada, vide nota 1$)$. 